\title{
THE SOCIO-ECONOMIC AND SPATIAL TRANSFORMATION OF POLISH CITIES AFTER I 989
}

\author{
Jerzy J. Parysek \\ Institute of Socio-Economic Geography and Spatial Management, \\ Adam Mickiewicz University, Fredry 10, 6I-70I Poznań, Poland \\ e-mail: parys@amu.edu.pl
}

\begin{abstract}
The aim of this paper is to present the socio-economic and spatial transformation of Polish cities after 1989. The Polish changes reached the structures of the three basic subsystems of the state: political (power), social (society), and economic (the economy). The systemic transformation that has taken place in Poland after 1989 is most readily visible in towns, although it was introduced in the country as a whole. For the development and transformation of towns, the most important were the introduction of local government structures and the market model of the economy. The restitution of local government has ensured towns an authentic manager authorised to perform his function by the local community. The introduction of the market model to the economy has resulted in its privatisation and the appearance of enterprise and competition. Towns, especially the biggest cities, have become attractive locations for investment. Cities with a balanced economic structure and well-developed infrastructure had much better chances for growth to start with. Unfortunately, the transformation period has also had some detrimental effects, the most important being unemployment and all kinds of social deviance. However, Polish cities are certainly different today and resemble Western cities to a greater extent than did the so-called socialist towns built along theoretically beautiful but practically ineffectual ideological lines.
\end{abstract}

Key words: transition, socio-economic transformation, spatial transformation, cities, Poland

\section{INTRODUCTION}

The systemic changes initiated in 1989 in Poland were revolutionary. They have brought about a fundamental transformation of the principles of the organisation and operation of the State, society and economy. So since 1989 year we have, in Poland and the other postCommunist states a completely new reality. Regained freedom and democracy opened the way for many factors of socio-economic development and structural change: not only endogenous but also exogenous. The aim of this paper is to present the socio-economic and 
spatial transformation of Polish cities after 1989. It is impossible, of course, to present all of changes having place in polish cities. So my presentation will be only limited to those that have been the most significant and that have fundamentally character and meaning. The Polish changes reached the structures of the three basic subsystems of the state: political (power), social (society), and economic (the economy). They embraced the organisation, structure and operation of each of the subsystems and the state system as a whole. Political subsystem were of fundamental importance, because created totally new conditions for the economy and society to operate in. The principles of Poland's political subsystem changed almost overnight. The so-called socialist democracy (or people's democracy, or feasible socialism) was replaced with the classic model of the democratic system (parliamentary democracy, political pluralism, civil society). The introduction of the market rules to the economy took several months, but crystallisation of the state's economic system seems to be an ongoing process. The transformation of the social subsystem will probably take the longest, mainly due to its inertia. The rebirth of a truly free, creative, enterprising, responsible and self-organising civil society seems likely to be a matter, not of one but two, if not three, generations. There is no doubt that after 1989 Poland became a democratic state with the economy running along market lines, and the effects of changes, although not always felt by society, are clearly noticeable.

\section{LOCAL GOVERNMENT AS MANAGER POF POLISH CITIES}

In 1990, power in local units, also cities, was transferred to reborn local government structures (The principles on which local government operates in Poland are laid down in the Local Government Act of 8 March 1990, with later amendments). Local government has also become the basic territorial structure of a civil society, and structure of local administration. It also performs certain tasks of state administration when given such orders. Local authorities at the commune level have a special role to play in initiating, planning, co-ordinating and implementing the socio-economic development of the commune, and in pursuing spatial development policy and issuing decisions in this respect (Parysek 1997). There are several tasks following from the Local Government Act that local authorities have to undertake to satisfy the collective needs of their communities. They are concern such issues as: (1) spatial order, land management and environmental protection; (2) communal roads, streets, bridges and squares as well as the organisation of road traffic and local public transport; (3) waterworks, water-supply service, sewerage, waste disposal and treatment, etc., as well as electricity, gas and heat supply systems; (4) health care and social help; (5) council housing; (6) education, culture and physical culture; (7) municipal green areas, market-places and market-halls, as well as municipal cemeteries; (8) public order and fire prevention; and (9) maintenance of communal objects and public utilities. There are also several tasks connected directly or indirectly with running the local economy. They include especially: (1) passing the commune budget as a basic source of financing the activities undertaken by the commune; (2) passing the spatial development plan, which is a model of the commune's spatial development, a systemic tool for steering this development, and a set 
of rules for the commune's residents and economic entities; (3) passing economic programmes (specific or general), including the commune's strategy of socio-economic development; and (4) passing resolutions concerning property matters, taxes, raising loans, making investments, contracting liabilities, creating and liquidating establishments, taking over tasks from government administration, co-operation with other communes, etc. (cf. Ratajczak, Wojtasiewicz 1996; Szewczyk 1996; Grobelny 1996; Parysek 1995, 1996, 1997; Niewiadomski 2002). In performing their statutory tasks, city authorities undertake several activities that are intended to solve problems of their local milieu. Especially important among them are attracting investors and thus creating new jobs, improving the quality of the natural environment, developing the city's technical infrastructure, and improving the service of the population. Practically every Polish town has an approved strategy of socioeconomic development, a comprehensive programme of the town's development, which it is now implementing and which is. A serious obstacle to carrying out all intentions is the meagreness of municipal budgets in relation to needs. The meagreness results from the state's financial policy, a sluggish economy, the slack rate of economic development, the pauperisation of society, difficulties with tax collection etc. However, as everything else in the country, the scope of the strategies and local development plans, as well as their anticipated effects, are limited by the permanently tight and unbalanced budgets. Hence, what we deal with in Poland is a paradoxical situation in which there is hardly any relation between the remit of the municipal authorities as defined by the legislature and the means they have at their disposal.

\section{THE NEW URBAN ECONOMY}

Since 1990 the Polish economy has been working on the market principles. The modern market economy, also Polish, can be shown to have several characteristics, such as: (1) equality of economic entities, (2) openness to the outside, (3) privatisation of the state-run sector, (4) development of private enterprise, (5) competition on local markets, (6) a regulatory role of the market, (7) competitiveness of economic entities, (8) a balanced structure of the economy in terms of sectors, size of enterprises, and spatial patterns, and (9) the emergence and development of business environment services (Naturally, the Polish economy has also other features, but these seem to be the most important ones). In the case of towns, the most important factors in their growth have been the privatisation of the economy, the development of enterprise, the emergence of business environment institutions, foreign direct investment, innovativeness, and scientific and technological progress. The privatisation of the economy has progressed at various rates. Its high initial dynamics slackened gradually. In some sectors privatisation has almost attained a $100 \%$ level, mainly in trade and services. Privatisation has been advancing steadily in construction, transport, health care, finance, education, and higher education. Naturally, in cities still existing a big state enterprises, often the biggest in the given city. Some of them have monopolistic positions, which conflicts with the rules of free competition. The private sector accounts for more than $50.8 \%$ of total urban employments, so means that a large number of people working in 
the public sector. The public sector embraces not only economic entities, but also state administration and local government units, administration of justice, public order units, and the huge sphere of public utilities. A very significant feature of the Polish economic transformation, especially readily visible in towns, has been the establishment (and fall) of many small and medium-sized businesses in every domain of economic activity. The most numerous are small trading firms and craft workshops. There is a very large sector of selfemployment, especially in broadly understood services. This is due to the fact, that many persons, especially in the professions, have decided to work on their own: in financial, legal or tax counselling, property management, health care, nursing services, and many other kinds of activity. (In 2000 there were slightly more than 2.8 employees per firm 2,8 in towns). The market model of the economy has created a clear demand among economic entities for specialised services called business environment services. This sector of the economy embraces commercial banks; insurance companies; financial, accounting and tax consulting establishments; agencies of economic development; chambers of commerce and industry; information technology firms; technological parks and entrepreneurship incubators, and so on. Institutions of this type abound mostly in cities, especially the biggest. Business environment firms play a significant role in the economies of Warsaw, Poznan, Wrocław, Cracow, Gdańsk, Gdynia, as well as Łódź, Szczecin, and Lublin. Practically all major European banks have their representatives in Warsaw, and so have global consulting firms. The systemic transformation has also brought changes in production techniques, technology, and organisation. Many new solutions have been introduced through the purchase of licences and own inventiveness. As a result of this process is modernisation of machinery, and technological and organisational changes. There has been a marked increase in the contribution of the productivity of labour and fixed assets to production growth. The of technological changes has been an improvement in the state of the natural environment, visible in practically each of its aspects. An important factor of economic restructuring has been foreign investment, which exceeded $\$ 65$ billion over the transformation period. A great many well-known global firms have entered the Polish market: Philips, Fiat, General Motors, Daewoo, Hyundai, Volkswagen, FranceTelkom, MAN, PepsiCo, Coca-Cola, Nestle, Wrigley, Procter \& Gamble, Henkel, Unilever, GlaxoSmithKline (formerly Glaxo-Welcome), McDonald's, KFC, IKEA, and other, which invested through a variety of investment groups, both in existing enterprises and in new, modern ones which have changed Polish industry radically. Investment was also made in a new field in Poland, namely commercial banking, insurance, and financial services. Thanks to foreign investment, dozens of big shopping centres and supermarkets have been set up (e.g., Metro, Makro, Géant, Auchan, Hit/Tesco, Jumbo/Hypernova, Intermarché, and Leroy-Merlin, which operate using various combinations of capital and often change their names), and the demand in this field, at last free from rationing and queues, has stimulated local markets. There have also appeared hundreds of petrol stations (Shell, BP, Texaco, Aral, Esso, Statoil, Preem, and other) whose location was a response to a motorisation explosion. These investments have largely concentrated in big cities, especially Warsaw, and their immediate zone of influence. An unintended adverse effect of the economic changes has been unemployment, practically nonexistent before 1989 . This is primarily an urban problem. The 
high unemployment rate results from the interaction of several endogenous and exogenous processes (Parysek 1993): (1) the economic transformation was launched during a prolonged crisis (lasting practically since 1976); (2) the Communist system, whose member states were the principal recipients of Polish industrial goods, had disintegrated and as a result many large industrial plants employing thousands of workers went bankrupt, primarily those that had been geared to the military-economic complexes of the Warsaw Pact and the USSR; (3) the new model of the economy has changed its structure fundamentally; (4) the new rules of economic activity have forced more rational employment; (5) technological progress has markedly reduced the demand for labour; (6) the rate of Poland's economic growth, highly dynamic in the early 1990s, has slackened considerably which social polarisation has deepened, as a result of which the domestic market has broken down; (7) there have appeared problems involved in postindustrial development and globalisation, and (8) a crisis in the world economy has developed, especially in the USA, Western Europe, and Japan and other Far-Eastern countries. All this has led to a serious drop in employment, and Polish unemployment has been structural and functional from the start, with internal and external determinants. There is a readily visible dependence between the unemployment rate in Polish cities and their size and economic structure. Bigger ones and those with a diversified structure tend to have lower unemployment figures. While the national unemployment rate at year's end was $16 \%$ in 2000 , in towns the figures ranged from $3.3 \%$ to nearly $40 \%$.

\section{CHANGES IN THE ECONOMIC STRUCTURE}

The changes in economic structure have been produced by a lot of factors: the adoption of a new economic model, Poland's opening to the world, competition on world markets, the internal balance on the market and establishing a connection between production and the market's needs, depriving trade of all ideological underpinnings and changing its geographical directions, technological changes, innovativeness, a change in the population's lifestyles, and many other. Enterprises manufacturing means of production started to be replaced by those producing consumer goods, which had usually been in short supply before 1989. At the same time, largely owing to foreign investment, many modern industrial plants were set up employing advanced technology to produce high-quality technical goods. The sellers' market turned into the buyers' market, and marketing practices, especially advertising, had to be developed to attract the consumer. Liquidated industrial jobs were replaced by new ones created in a broadly understood service sector. Growth dynamics was particularly high in trade, financial services, insurance, building and plumbing services, the real estate market, medical, nursing and recreational services, education, repairs, transport, communications, and telecommunications. Homogeneous economic structures were gradually replaced by more diversified ones ensuring a measure of equilibrium in the given sector or industry (Parysek 1998a, 1998b). Out of total employment in Polish cities, industry and construction account for 39.1\%; market services, 33.7\%; non-market services, also $33.7 \%$; and other fields of economic life, $0.7 \%$. The situation differs from town to town. 
Principal components analysis carried out for 33 cities and 12 variables characterising the demographic situation, unemployment, the economy, social infrastructure, and urban budgets revealed basic levels differentiating the towns. In 1992, they were: at the first level (with 26.73\% variance), the demographic situation and unemployment; at the second level $(21.33 \%$ variance), the level of economic activity and social infrastructure; at the third level (15.58\% variance), unemployment and the housing standard; and at the fourth level (11.26\% variance), budgetary revenue and the municipal road system. In 2000, what differentiated the set of 33 Polish towns at the first level (with $31.46 \%$ variance) were social infrastructure, the housing standard, and the urban budget; at the second level $(22.44 \%$ variance), economic activity and unemployment; at the third level (14.25\% variance), population distribution and the municipal road system; and at the fourth level (10.68\% variance), the demographic situation. Generally, however, the differences among the towns in 1992, with the 12 variables considered, were less marked than in 2000, although their similarity in both years was great. In 1992, the towns that stood apart were Łódź, Gdańsk and Gdynia; in both 1992 and 2000, Warsaw, Chorzów and Białystok; and in 2000, Dąbrowa Górnicza, Rybnik and Rzeszów (Table 1). The differences among the remaining towns of the set were slight.

Table 1. Principal components of the socio-economic structure of 33 largest Polish cities and variables defining them.

\begin{tabular}{|c|c|c|c|}
\hline \multicolumn{2}{|c|}{$\begin{array}{l}\text { Principal components } \\
\text { (variance) }\end{array}$} & \multirow{2}{*}{$\frac{1992}{\text { variables }}$} & \multirow{2}{*}{$\frac{2000}{\text { variables }}$} \\
\hline 1992 & 2000 & & \\
\hline$V_{1}=26.73 \%$ & $\mathrm{~V}_{1}=31.46 \%$ & $\begin{array}{ll} & \text { population density } \\
& (52.8 \%) \\
\text { - } & \text { natural increase }(51.2 \%) \\
\text { - } & \text { unemployment rate } \\
& (44.5 \%) \\
\text { - } & \text { dependency ratio }(38.7 \%) \\
\end{array}$ & $\begin{array}{ll}\text { - } & \text { pupils of secondary schools } \\
\text { per } 1,000 \text { population }(96.9 \%) \\
\text { - } & \text { area of flat }(82.3 \%) \\
\text { - } & \text { doctors per } 10,000 \text { population } \\
& (85.5 \%) \\
\text { - } & \text { commune's budgetary income } \\
\text { per head }(64.2 \%)\end{array}$ \\
\hline $\mathrm{V}_{2}=21.33 \%$ & $\mathrm{~V}_{2}=22.44 \%$ & $\begin{array}{ll}- & \text { doctors per } 10,000 \\
& \text { population }(58.5 \%) \\
\text { - } & \text { pupils of secondary } \\
\text { schools per } 1,000 \\
& \text { population }(54.5 \%) \\
\text { - } & \text { economic entities per } \\
& 1,000 \text { population }(54.2 \%) \\
\text { employment per } 1,000 \\
\text { population }(40.1 \%)\end{array}$ & $\begin{array}{ll}- & \text { unemployment rate }(78.8 \%) \\
\text { - } & \text { employment per } 1,000 \mathrm{popu}- \\
& \text { lation }(68.8 \%) \\
\text { - } & \text { economic entities per } 1,000 \\
& \text { population }(63.0 \%)\end{array}$ \\
\hline $\mathrm{V}_{3}=15.58 \%$ & $\mathrm{~V}_{3}=14.25 \%$ & $\begin{array}{ll}- & \text { area of flat }(67.0 \%) \\
& \text { unemployment rate } \\
& (38.3 \%)\end{array}$ & $\begin{array}{ll} & \text { population density }(70.3 \%) \\
- & \text { density of local roads }(32.7 \%)\end{array}$ \\
\hline $\mathrm{V}_{4}=11.26 \%$ & $\mathrm{~V}_{4}=10.66 \%$ & $\begin{array}{ll}\text { - } & \text { density of local roads } \\
& (30.0 \%) \\
\text { - } & \text { commune's budgetary } \\
\text { income per head }(35.9 \%)\end{array}$ & $\begin{array}{ll}- & \text { natural increase }(56.2 \%) \\
- & \text { dependency ratio }(31.2 \%)\end{array}$ \\
\hline
\end{tabular}

Source: Own calculations. 


\section{METROPOLITANISATION}

One of the effects of the systemic transformation in Poland has been the process of metropolitanisation of cities. A metropolis is generally taken to be a great city with an exceptionally high concentration of globalisation effects. However, not every big city is a metropolis, but one with well-developed metropolitan functions (contents) and metropolitan spatialfunctional structures (forms). Many scholars are of the opinion that the process of metropolistanisation has also been going on in the largest Polish cities, albeit at a lazy pace recently except in Warsaw, and its effects are readily visible. Warsaw is undoubtedly a metropolis of the subcontinental rank, vying for its international position with the dynamic Budapest and Prague (Kukliński 2000; Lever 2000). However, as the second largest investment site in Central Europe after Berlin, Warsaw has a chance to win the competition. The city has been developing metropolitan functions and the proper spatial-functional structures. Metropolises at the national scale probably include Poznań, Wrocław and Cracow, and possibly also Gdańsk, or rather the entire Trójmiasto (Tri-City) of Gdańsk, Gdynia and Sopot. (Lever 2000; Kukliński 2000), Szczecin and Lublin seem to have even smaller chances in this respect. Their development depends to a lesser extent on the domestic situation than on the one abroad. The future of Szczecin will be decided in Berlin, while that of Lublin will be determined by the economic and political situation in Ukraine, Belarus and Russia. As has been mentioned, the process of metropolitanisation of Poland's largest cities keeps progressing, although slowly and not without difficulties. It seems that a serious acceleration can only be expected after Poland has joined European Union structures, and if the pattern of globalisation turns out to be favourable to the country. Given the serious financial shortages of Polish towns and the country as a whole, as well as sharp differences in economic development and the standards of living in Poland and the West, the progress of metropolisstanisation will probably depend on external rather than internal factors. The former will be the actual driving force of metropolitanisation, while the latter can only play the role of catalysts or factors smoothing the course of this process (cf. Jałowiecki 2000; Parysek 1995, 2000, 2001, 2002a, 2002b).

\section{SPATIAL CHANGES}

The changes in the economies and social lives of Polish towns are gradually being followed by changes in their spatial development. In big cities, readily visible are: appearance of stretches of streets offering prestigious shopping; (2) the appearance of modern, though low-standard, outlying shopping centres, (3) the delineation and development of new investment areas, also on city peripheries; (4) the modernisation of communication routes and limitation of wheeled traffic in city centres as well as the construction of car parks, includeing so-called 'buffer' ones along the margins of the downtown districts; (5) a change in the model of residential construction manifesting itself in the building of small, often 'closed', housing estates with an atmosphere of their own whose architecture departs radically from the typical unimaginative blocks of flats of the socialist period; (6) the undertaking of pro- 
jects for the renewal of the historic urban architecture, including residential buildings, areas formerly in industrial, transport, and military use, old storehouses, and to a very modest extent, high-rise estates of the 1950s and '60s; the projects meet with obstacles of various kinds and suffer from serious shortages of financial means; (7) the development of singlefamily housing in the suburban zone; and (8) attempts at deconcentration of building, especially in compactly built towns, which is intended to improve the functionality of communication routes and 'decongest' the downtown district (Parysek 2002a, 2002b). In this way steps have been taken to introduce a new model of the Polish city. Due to its richer, more diversified spatial structure, it starts to resemble the cities in West European countries. In practice, this means an ultimate departure from the idea of a socialist city, whose symbols were neglected and crowded centres with a relatively well-developed network of shops and services, underinvested as far as other necessary facilities were concerned, large estates of low-standard blocks of flats, and zones of usually heavy-industry plants employing obsolete technologies.

\section{NEW URBAN STRUCTURE}

The Poland's former socio-political situation could not but be reflected in the city. In accordance with ideological assumptions, the conception of the so-called socialist city was implemented, with patchy success. In fact, this was an eclectic type of town in which uniform, rather poor local communities lived in the conditions of underdeveloped technical and social infrastructure. The new architecture of those towns featured objects whose style was termed social realism. The style affected equally residential buildings (blocks of flats), those of people's authority (state and Party administration, the police and security), public utility buildings, and shopping pavilions. In its spatial form, it was a concentric city whose core was the historic architecture of the marketplace and its environs. The core was enveloped by residential and industrial buildings from the 19th and 20th centuries, and these were surrounded, or penetrated, by a postwar building pattern of low-standard blocks of flats. They formed bigger or smaller barracks-type housing estates, depending on the size of the city and its function; they were called the city's dormitories and usually suffered from serious underdevelopment of services. The estates were composed of low-standard, simple, solid-like, uniform blocks of flats made of prefabricated units. Simply, blocks of flats were built together with access roads, the necessary public transport (mostly buses) was organised, and the whole was equipped with 'estate service centres' which included a primary school, ambulatory-patient medical facilities with a pharmacy, and a shopping centre with a grocery, a post office, a few shops with industrial goods, a few service establishments, and a community centre. The housing-estate infrastructure was unable to satisfy many basic needs of the residents, however, which forced them to arrange many matters in the central part of the city. The living conditions in such cities were hard for most of their residents. They deteriorated as the population increased, because the increase was not matched by municipal investment and the existing infrastructure. Polish urbanisation started to be increasingly deformed urbanisation. Still, towns acted like a magnet for people from the 
backward countryside, because they offered education and jobs unavailable at home. This situation, little changed, prevailed until the end of 1989. The collapse of the communist system and the disintegration of the Eastern bloc of states, as well as their immediate steps to build their own democratic systems with market economies open to the world and civil societies, seem to have brought global factors and tendencies to the fore in the development of towns. Since 1989 the face of the Polish and Central European city has been changing. However, the change has been almost exclusively qualitative, and far from those expected. The towns do not offer new jobs any more, as in the days of old. On the contrary, the transformation of the economy, market principles of business operation, and ever more employed new technologies have led to an increasing number of redundancies which are not offset by new jobs being created in trade and services. Today, not the city itself but its suburban zone is more attractive, because one can get a flat there for a lower price and ensure oneself better living conditions, both in economic and ecological terms. All these factors are responsible for the process of depopulation that can be observed in cities recently. On the other hand, Polish cities are becoming more and more neat and tidy, more beautiful, and more functional. Sanitary conditions have improved, and expansion follows plans of spatial development. The cities are ruled by democratically elected local governments whose basic task is to statisfy the collective needs of the local communities. From day to day, Polish cities are becoming more social than socialist, because they no longer serve any ideology but their residents, and this is what their growth is all about.

\section{CONCLUSION}

The systemic transformation that has taken place in Poland after 1989 is most readily visible in towns, although it was introduced in the country as a whole. Its effects are most conspicuous in these settlement units because they bring together many people and diverse economic activities in a small area. For the development and transformation of towns, the most important were the introduction of local government structures and the market model of the economy. These two factors had a direct impact on urban growth. The restitution of local government has ensured towns an authentic manager authorised to perform his function by the local community. The introduction of the market model to the economy has resulted in its privatisation and the appearance of enterprise and competition. These changes, accompanied by new technologies, have not only improved economic performance, but also seriously lessened the environmental pollution load. Market rules have substantially contributed to the restructuring of the economy in each of its dimensions, that is, ownership, sectoral, size, and spatial. Towns, especially the biggest cities, have become attractive locations for investment. Cities with a balanced economic structure and welldeveloped infrastructure had much better chances for growth to start with. Numerous small and medium-sized businesses began to be set up, and it is they that have changed the economic structure in such a way that broadly understood services and not industry play the most important role today. Indirect effects of the transformation embrace everything related to Poland's opening to the world, including the effects of globalisation. Unfortunately, the 
transformation period has also had some detrimental effects, the most important being unemployment and all kinds of social deviance. However, Polish cities are certainly different today and resemble Western cities to a greater extent than did the so-called socialist towns built along theoretically beautiful but practically ineffectual ideological lines.

\section{References}

Chojnicki Z., Czyż T., Parysek J. 1995: Przekształcenia i dylematy polskiej gospodarki. W: Proces przekształceń społeczno-gospodarczych w Europie Środkowej i Wschodniej po roku 1989 (red. F. W. Cartrer., W. Maik). Turpress. Toruń. 15-36.

Chojnicki Z., Czyż T., Parysek J., 1999: Transformations and dilemmas of Polish economy. In: Carter W.F., Maik W. (eds), Shock-shift in an enlarged Europe. The geography of socio-economic changes in East-Central Europe after 1989. Aldershot: Ashgate, 7-26.

Dutkowski M. 1995: Konflikty w gospodarowaniu dobrami środowiskowymi. Wydawnictwo Uniwersytetu Gdańskiego. Gdańsk.

Grobelny R. 1996: Narzędzia ekonomiczno-finansowe sterowania rozwojem przestrzennym skali lokalnej. W: Rozwój lokalny i lokalna gospodarka przestrzenna. (red. J. Parysek). Bogucki Wydawnictwo Naukowe. Poznań, 141-168.

Jałowiecki B. 2000: Społeczna przestrzeń metropolii. Wydawnictwo Naukowe Scholar. Warszawa.

Korcelli P. 1999: Warsaw. The eastern end of the trajectory. W: Domański R. (ed.), The changing map of Europe: The trajectory: Berlin-Poznań-Warsaw, Warsaw: Friedrich Ebert Stiftung, 141-149.

Kukliński A., 2000: The Warsaw metropolis and the challenges of globalization (W:) The European challenges of the 21 st century. The knowledge-based economy (red. A. Kukliński). KBN. Warsaw, 240-251.

Lever W.F., 2000: Warsaw. A global metropolis of the Twenty-First Century. (W:) The European challenges of the 21 st century. The knowledge-based economy (red. A.Kukliński).KBN. Warsaw, 202-214.

Niewiadomski Z. 2002: Planowanie przestrzenne. Zarys Systemu. Wydawnictwo Prawnicze LexisNexis. Warszawa.

Parysek J. 1993: Unemployment - a socially painful stage in the transition from a centrally planned to a market economy: The case of Poland. European Planning Studies , 1-2., 231-240.

Parysek J. 1995: Duże miasta Europy i ich rola w procesie urbanizacji, rozwoju społecznogospodarczego i europejskiej integracji u schyłku XX wieku. Przegląd Geograficzny. 67. 3 - 4., 225 - 248.

Parysek J. 1996: Gospodarka lokalna w warunkach wolnego rynku i samorządowych struktur społecznych. W: Rozwój lokalny i lokalna gospodarka przestrzenna. (red. J. Parysek). Bogucki Wydawnictwo Naukowe. Poznań, 31-46.

Parysek J., 1997: Podstawy gospodarki lokalnej. Poznań: Wydawnictwo Naukowe UAM Poznań. 
Parysek J. 1998: Efekty procesu transformacji społeczno-gospodarczej w Polsce. Bilans okresu 1989-1996. W: Przemiany społeczno-gospodarcze Polski lat dziewięćdziesiątych. (red. J. Parysek, H. Rogacki). Bogucki Wydawnictwo Naukowe. Poznań, 25-46

Parysek J. 2000: Polskie metropolie jako ogniwa procesu transformacji i przemian przestrzenno-strukturalnych (na tle metropolii europejskich), (W:) Uwarunkowania i strategie rozwoju regionalnego $\mathrm{w}$ procesach integracji europejskiej (Red. Z. Mikołajewicz). Wydawnictwo Uniwersytetu Opolskiego. Opole, 347 - 360.

Parysek J. 2001: Główne problemy i kierunki rozwoju miast polskich na tle przemian strukturalnych miast Europy (W:) Nowoczesne zarządzanie rozwojem miast (red. A. Billert). Collegium Polonicum UAM Poznań w Słubicach. Projekt Tempus - PHARE „Nowoczesne zarządzanie rozwojem miast”. Słubice, $51-75$.

Parysek J. 2002a: Metropolises and the processes of metropolitanisation. Geographia Polonica. 75. $2,25-43$.

Parysek J. 2002b: Wewnętrzne i zewnętrzne uwarunkowania transformacji przestrzenno strukturalnej i rozwoju miast polskich w końcu XX wieku (W:) Przemiany bazy ekonomicznej i struktury przestrzennej miast (red. J. Słodczyk). Uniwersytet Opolski. Opole. $15-32$.

Parysek J, Dutkowski M. 1994a: Going green. European Planning Studies, 4, 419-434.

Parysek J., Dutkowski M. 1994b: Koncepcja ekorozwoju i jej technologiczne oraz społeczno-polityczne uwarunkowania. Przegląd Geograficzny, t. 66, z.1-2, 3-18.

Ratajczak A., Wojtasiewicz L. 1996: Plan przestrzennego zagospodarowania jako systemowe narzędzie sterowania rozwojem lokalnym. W: Rozwój lokalny i lokalna gospodarka przestrzenna. (red. J. Parysek). Bogucki Wydawnictwo Naukowe. Poznań, 155 196.

Szewczyk M. 1996: Prawne narzędzia sterowania rozwojem przestrzennym. W: Rozwój lokalny i lokalna gospodarka przestrzenna. (red. J. Parysek). Bogucki Wydawnictwo Naukowe. Poznań, 47-66. 